\title{
LITERATUR REVIEW: SISTEM SOSIAL MODEL PEMBELAJARAN PROBLEM SOLVING TERHADAP SIKAP SOSIAL SISWA
}

\author{
Weni Sukarni $^{1^{*}}$, Astalini², Dwi Agus Kurniawan ${ }^{3}$ \\ $1^{*, 2,3}$ Physics Education, Universitas Jambi, Indonesia \\ * Corresponding Author. E-mail: ${ }^{1 *}$ wenisukarni282.ws@gmail.com, \\ astalinizakir@unja.ac.id, ${ }^{3}$ dwiagus.k@unja.ac.id
}

\begin{tabular}{|l|l|l|}
\hline Receive: 19/01/2021 & Accepted: 28/02/2021 & Published: 04/03/2021
\end{tabular}

\begin{abstract}
Abstrak
Salah satu upaya untuk meningkatkan kualitas pendidikan dengan menerapkan model pembelajaran berbasis masalah yakni model pembelajaran problem solving sebagai suatu strategi yang diharapkan mampu meningkatkan sikap siswa dalam proses pembelajaran dan menjadikan proses pembelajaran lebih bermakna bagi siswa. Penelitian ini adalah penelitian studi literatur dengan metode penelitian kualitatif deskriptif melalui studi pustaka yang mengkaji tentang implementasi sistem sosial model pembelajaran problem solving dalam upaya meningkatkan sikap siswa. Penelitian studi literatur ini bersumber dari artikel ilmiah, jurnal, dan dokumen penelitian relevan yang berkaitan dengan penelitian ini. Fokus penelitian ini adalah implementasi sistem sosial model pembelajaran problem solving. Berdasarkan hasil dari studi literatur dapat disimpulkan bahwa sistem sosial dari model pembelajaran problem solving yang telah diterapkan belum sepenuhnya memenuhi tuntutan dalam kurikulum 2013. Hal ini terlihat pada penelitian terdahulu bahwa sistem sosial model pembelajaran problem solving belum mengakomodasi perbaikan sikap sosial siswa. Oleh karena itu, perlu dilakukan sebuah pengembangan terhadap sistem sosial model pembelajaran problem solving untuk meningkatkan sikap sosial siswa.
\end{abstract}

Kata Kunci: Sistem Sosial, Problem Solving, Sikap Sosial

\begin{abstract}
One of the efforts to improve the quality of education is by applying a problem-based learning model, namely the problem solving learning model as a strategy which is expected to improve students' attitudes in the learning process and make the learning process more meaningful for students. This research is a literature study with descriptive qualitative research method through literature study which examines the implementation of social systems of problem solving learning models in an effort to improve student attitudes. This literature study research is sourced from scientific articles, journals, and relevant research documents related to this research. The focus of this research is the implementation of a social system problem solving learning model. Based on the results of the literature study, it can be concluded that the social system of the problem solving learning model that has been implemented has not fully met the demands of the 2013 curriculum. This can be seen in previous studies that the social system of problem solving learning models has not
\end{abstract}


accommodated the improvement of students' social attitudes. Therefore, it is necessary to develop a social system of problem solving learning models to improve students' social attitudes

Keywords: Social Systems, Problem Solving, Social Attitudes

\section{Pendahuluan}

Pendidikan adalah suatu bekal untuk mengembangkan kreatifitas diri guna mencapai sebuah keinginan.Muslim (2015:65) menyatakan bahwa pendidikan juga merupakan wahana yang dapat meningkatkan dan mengembangkan kualitas dari sumber daya manusia. Dunia pendidikan erat kaitannya dengan proses belajar mengajar yang merupakan suatu kegiatan dalam rangka melaksanakan kurikulum suatu lembaga pendidikan, agar dapat mempengaruhi para siswa mencapai tujuan pendidikan yang telah ditetapkan (Mulati dkk, 2014:113).

Pembelajaran pada hakikatnya adalah suatu proses, yaitu proses mengatur, mengorganisasi lingkungan yang ada di sekitar peserta didik sehingga dapat menumbuhkan dan mendorong peserta didik melakukan proses belajar (Pane, 2017:337). Kendala yang sering dihadapi oleh guru dalam menerapkan kurikulum 2013 adalah pemilihan model pembelajaran. Salah satu faktor yang mempengaruhi proses pembelajaran adalah sikap. Pendapat dari Sari dkk (2019:103), sikap merupakan kemampuan seseorang untuk bertindak yang diwujudkan melalui rasa senang atau tidak senang terhadap suatu objek.

Berdasarkan penelitian oleh Zahara dkk (2017:3), sikap siswa merupakan indikator dalam penentu keberhasilan siswa dalam mengikuti proses pembelajaran. Maka, untuk mengetahui keberhasilan belajar siswa dapat ditinjau dari sikap yang dimiliki oleh siswa.Kompetensi sikap menjadi konsentrasi kurikulum 2013 karena pada kurikulum sebelumnya kurang diperhatikan. Salah satu aspek penting yang perlu dihadirkan dalam proses pembelajaran adalah sikap spiritual dan sikap sosial. Kedua sikap tersebut dirumuskan dalam kompetensi inti I (KI-1), dan kompetensi inti II (KI-2).Sikap spiritual adalah sikap yang berhubungan dengan pembentukan moral siswa berdasarkan keimanan dan ketakwaan kepada Tuhan Yang Maha Esa.Sedangkan sikap sosial adalah sikap yang berhubungan dengan kehidupan sosial sebagai bentuk interaksi siswa dengan alam, lingkungan sekolah, dan lingkungan sekitar (Gusviani,2016:98).

Salah satu unsur model pembelajaran adalah sistem sosial.Dalam konteks ini, sistem sosial mendeskripsikan peranan guru dengan siswa, interaksi antara guru dengan siswa, dan target yang diharapkan (Sugiono dkk, 2016:27). Prinsip yang terkandung dalam pola interaksi sistem sosial adalah bekerja sama menyelesaikan masalah antara guru-siswa, siswa-siswa, maupun kelompok, dan kebebasan mengemukakan pendapat. Oleh karena itu, esensi sistem sosial pada model pembelajaran problem solving yaitu bagaimana cara pandang antara komponen dalam kelompok belajar, sehingga timbul rasa nyaman di antara kelompok dalam memecahkan masalah yang dihadapi (Widiawati,2018:3).

Penerapan model pembelajaran problem solving masih terdapat kekurangan yaitu hanya terfokus pada ranah kognitif yang lebih mengutamakan pencapaian pengetahuan.Implementasi sistem sosial dalam pembelajaran berbasis pemecahan masalah ini mencakup peran dan hubungan siswa dengan guru secara rinci pada setiap tahap pembelajaran.Namun, sistem sosial yang telah diterapkan belum mengakomodasi perbaikan sikap sosial yang termuat dalam kompetensi inti II (KI2) kurikulum 2013 revisi.Sementara itu, tuntutan kurikulum 2013 revisi juga mengedepankan ranah afektif seperti sikap sosial. Berdasarkan permendikbud No. 65 Tahun 2013 tentang Standar Proses Pendidikan Dasar dan Menengah pada bab 
tentang karakteristik pembelajaran menyatakan bahwa proses pembelajaran sepenuhnya diarahkan pada pengembangan ketiga ranah meliputi afektif, kognitif dan psikomotor secara utuh, artinya pengembangan ranah yang satu tidak bisa dipisahkan dengan ranah lainnya.

Pemilihan model pembelajaran problem solving didasari oleh hasil penelitian dari Abduhan dkk (2015:72) menyatakan bahwa model pembelajaran problem solving cocok digunakan dalam merubah aktivitas dan sikap siswa.Model pembelajaran problem solving dipilih untuk mengedepankan pola pembelajaran yang berpusat pada siswa dan mengarah pada pembelajaran aktif, inovatif, kreatif, menyenangkan, bermakna serta produktif guna menyeimbangkan peran guru. Salah satu upaya untuk menyeimbangkan peran guru dan siswa serta menciptakan komunikasi yang dinamis dalam proses pembelajaran dapat melalui sistem sosial.

Keberhasilan proses pembelajaran di sekolah tidak terlepas dari kemampuan dan kreativitas guru dalam memodifikasi model pembelajaran yang berpusat pada siswa, dan berorientasi pada keterlibatan siswa secara aktif (Nurwidyastuti, \& Wutsqa,2016:35). Selain itu, salah satu upaya untuk menghadapi perbedaan karakteristik siswa perlu suatu modifikasi dari sistem sosial model pembelajaran problem solving yang disesuaikan dengan lingkungan belajar, dan tujuan pembelajaran dalam kurikulum 2013 revisi. Dengan demikian, peneliti tertarik mengkaji tentang "Implementasi Sistem Sosial Model Pembelajaran Problem Solving Terhadap Sikap Sosial Siswa".Penelitian ini bertujuan untuk mengetahui perlunya sebuah modifikasi dari sistem sosial model pembelajaran problem solving sebagai bentuk perbaikan sikap sosial siswa.

\section{Metode}

Penelitian ini adalah penelitian studi literatur dengan metode penelitian kualitatif deskriptif melalui studi pustaka yang mengkaji tentang implementasi sistem sosial model pembelajaran problem solving dalam upaya meningkatkan sikap siswa. Penelitian studi literatur ini bersumber dari artikel ilmiah, jurnal, dan dokumen penelitian relevan yang berkaitan dengan penelitian ini. Fokus penelitian ini adalah implementasi sistem sosial model pembelajaran problem solving. Beberapa kriteria dalam penelusuran artikel yaitu tentang model pembelajaran problem solving, kurikulum 2013, karakteristik siswa, dan sikap siswa yang terfokus pada sikap sosial. Studi literatur dilakukan dengan menelusuri publikasi artikel antara tahun 2010-2020 yang terindeks sinta ataupun scopus. Kemudian melakukan analisi terhadap beberapa artikel maupun dokumen relevan yang diperoleh. Selanjutnya menarik kesimpulan dan melakukan evaluasi terhadap penelitian sebelumnya tentang implementasi sistem sosial model pembelajaran problem solving.

\section{Hasil dan Pembahasan}

Suatu kurikulum harus memiliki kesesuaian atau relevansi. Kesesuaian ini meliputi dua hal. Pertama kesesuaian antara kurikulum dengan tuntutan, kebutuhan, kondisi, dan perkembangan masyarakat. Kedua kesesuaian antar komponenkomponen (Alinawati,2014:359). Berdasarkan hasil penelitian dari Mardiana \& Sumiyatun (2017:50), pandangan guru terhadap kurikulum 2013 bahwa kurikulum sangat membantu para guru, dimana guru memiliki peranan hanyalah sebagai penghantar serta sebagai motivator untuk siswa. Sedangkan pandangan siswa terhadap kurikulum 2013 bahwa siswa dijadikan aktif selama proses pembelajaran berlangsung. Sehingga dalam proses pembelajaran siswa diharapkan mampu aktif selama proses pembelajaran berlangsung dan diharapkan lebih mampu untuk memahami materi pelajaran yang dibahas.

Penerapan kurikulum 2013 dilakukan secara bertahap sejak awal pemberlakukannya di tahun 2013-2014. Sebagaimana diungkapkan Direktur 
Jenderal Guru dan Tenaga Kependidikan bahwa kurikulum 2013 telah diterapkan secara bertahap (Salim, \& Mujtahidah,2020:90). Beberapa dampak negatif dari penerapan kurikulum 2013, yaitu ketidakjelasan dalam sistem penilaian bagi siswa, waktu belajar di sekolah menjadi lebih lama. Selain itu, beberapa guru terlihat belum menguasai tentang pelaksanaan kurikulum 2013 dengan seutuhnya. Adapun dampak positif dari penerapan kurikulum 2013 ini, yaitu waktu istirahat lebih lama, dan siswa dituntut untuk lebih aktif dan kreatif sehingga siswa mampu mengembangkan potensinya dengan bebas. Dalam hal ini, siswa tidak hanya diasah dalam aspek intelektualnya, namun seluruh aspek yang dapat dikembangkan oleh siswa (Alinawati,2014:359).

Pentingnya komunikasi dalam pembelajaran dijadikan sebagai salah satu aspek yang dikembangkan untuk mendukung pembelajaran abad 21 dan kurikulum terbaru saat ini yaitu kurikulum 2013. Filosofi dari kurikulum 2013 adalah pendidikan untuk membangun kehidupan masa kini dan masa depan yang lebih baik, dimana perlu menekankan pada kemampuan intelektual, kemampuan berkomunikasi, sikap sosial, kepedulian, dan berpartisipasi untuk membangun kehidupan masyarakat dan bangsa yang lebih baik (Fadly,2018:146). Sehingga mengelola komunikasi yang efektif sangatlah penting karena dapat mengembangkan potensi.

Salah satu aspek yang mengalami perkembangan dari kurikulum 2013 dibanding kurikulum sebelumnya adalah penilaian. Pelaksanaan penilaian pada kurikulum 2013 secara eksplisit yang dilakukan guru harus seimbang antara tiga ranah domain, yaitu: kognitif, afektif dan psikomotor sesuai dengan tujuannya yang hendak diukur. Penekanan penilaian menyeluruh terhadap ketiga aspek dan sangat berperan dalam menentukan kesuksesan pendidikan (Setiadi,2016:167). Ketepatan pemilihan metode penilaian akan sangat berpengaruh terhadap objektivitas dan validitas hasil penilaian yang ujungnya adalah adalah informasi objektif dan valid atas kualitas pendidikan.

Kurikulum 2013 telah beberapa kali mengalami revisi. Substansi hasil revisi pada tahun 2017 berupa dokumen kurikulum 2013 yang meliputi: koherensi kompetensi inti-kompetensi dasar dan penyelarasan dokumen; penataan kompetensi sikap spiritual dan sikap sosial pada semua mata pelajaran; penataan kompetensi yang tidak dibatasi oleh pemenggalan taksonomi proses berpikir; dan pemberian ruang kreatif kepada guru dalam mengimplementasikan kurikulum (Suriadi,2018:42). Salah satu penentu keberhasilan Kurikulum 2013 adalah kesiapan guru yang dapat dilihat dari persepsi guru terhadap hambatan dan dukungan. Selain peran aktif siswa diperlukan juga peran aktif guru dalam proses pembelajaran. Adanya hubungan antara guru dan siswa dapat mengoptimalkan keberhasilan implementasi kurikulum 2013 revisi. Selain itu, implementasi suatu kurikulum dapat dikatakan terlaksana apabila guru maupun siswa berperan aktif dalam proses pembelajaran dan ada perubahan sikap pada siswa serta kesiapan guru dalam mendidik.

Seorang guru dalam perencanaan pembelajaran perlu mengidentifikasi karakteristik siswa untuk menetapkan spesifikasi dan kualisasi tujuan dan materi. Menguasai karakteristik siswa menjadi mutlak bagi tenaga pendidik, bahkan penguasaan karakteristik tersebut menjadi salah satu indikator profesional atau tidaknya seorang tenaga pendidik (Janawi,2019:1). Karakteristik siswa adalah ciri dari kualitas setiap siswa yang ada pada umumnya meliputi antara lain: kemampuan akademik, usia dan tingkat kedewasaan, motivasi terhadap mata pelajaran, pengalaman, keterampilan, psikomotorik, kemampuan kerjasama, serta kemampuan sosial (Taufik,2019:2). Jadi, Karakteristik siswa merupakan sebuah jati diri yang dimiliki siswa sebagai potensi sejak lahir, 
dan berkembang melalui proses sosialisasi nilai-nilai (Mustoip dkk, 2018).

Karakteristik siswa adalah sebuah keunikan yang dimiliki oleh setiap siswa dalam setiap proses pembelajaran (Nurhamidah,2018:28). Masing-masing siswa memiliki karakteristik yang berbedabeda sehingga guru kesulitan menghadapi perbedaan karakteristik siswa. Karakteristik siswa adalah salah satu variabel yang domain dengan desain pembelajaran akan memberikan suatu dampak terhadap keefektifan belajar siswa (Budiningsih,2011:167). Karakteristik siswa pada dasarnya dapat diidentifikasi dari berbagai sudut pandang diantaranya kemampuan awal siswa, latar belakang sosial-budaya siswa, hingga gaya belajar siswa. Setiap siswa memiliki gaya belajar yang berbeda-beda, hal itu dapat dilihat di kelas ada siswa yang terlibat aktif dalam pembelajaran dan ada pula yang cenderung pasif. Siswa harus mengenali bagaimana gaya belajarnya sendiri agar mudah menerima pembelajaran, sedangkan guru harus mengenali gaya belajar siswanya agar bisa menyiapkan strategi yang cocok untuk diajarkan (Chania dkk, 2017:78). Gaya belajar mengacu pada tiga bentuk kecenderungan dalam memproses informasi, yakni melalui indra penglihatan, pendengaran, dan seluruh tubuh/fisik (Wahyuni,2017:79).

Dalam proses belajar dan pembelajaran, seorang guru secara sadar ataupun tidak sadar akan membuat sebuah lingkungan tersendiri selama proses tersebut. Siswa dalam proses pembelajaran memerlukan konsentrasi yang tinggi, penerapan, dan penerimaan informasi. Oleh karena itu, lingkungan belajar yang kondusif perlu diwujudkan, sehingga siswa merasa nyaman dan belajar dengan konsentrasi yang tinggi (Yarmayani, \& Diliza,2018:136). Lingkungan yang baik tersebut bukan hanya sekedar berbicara tentang ruangan tapi juga tentang alam sekitar. Karena pada dasarnya sebuah pembelajaran tidak selalu harus berada dalam ruangan tetapi dapat memanfaatkan $\begin{array}{llrr}\text { pembelajaran } & \text { diluar } & \text { sekolah } & \text { atau } \\ \text { lingkungan } & \text { luar } & \text { (Saptono, } & \&\end{array}$ Suparno,2016:23).

Model pembelajaran problem solving merupakan model pembelajaran yang mampu membuat siswa melibatkan diri langsung kedalam persoalan materi pembelajaran, sehingga semakin aktif, dan mampu mempertanggungjawabkan hasil yang didapatkan (Octavia,2020). Esensi dari model pembelajaran problem solving siswa dituntut untuk berfikir secara ilmiah dan kritis, sehingga siswa akan lebih aktif dalam mengidentifikasi masalah, mengolah, dan merumuskan solusi yang terbaik dalam memecahkan masalah (Nurhidayati,2016:29). Karakteristik model pembelajaran problem solving yaitu model pembelajaran yang memerlukan keaktifan siswa untuk memahami masalah, mengorganisasikan, menemukan solusi, dan mengembang konsep-konsep atau gagasangagasan dengan pengetahuan yang dimilikinya (Buyung,2014:4). Melalui model pembelajaran problem solving siswa dilatih untuk menemukan solusi dari masalah yang diberikan oleh guru secara aktif, logis, dan kreatif dengan mengikuti langkah-langkah yang telah ditentukan meliputi klarifikasi masalah, pengungkapan gagasan, evaluasi dan seleksi, serta implementasi (Maesari dkk.,2020:14).

Menurut Utami, Utami, \& Sarumpaet (2018:176), ciri-ciri dari model pembelajaran problem solving yaitu:

a. Mengajukan pertanyaan atau masalah berdasarkan masalah bukan hanya mengorganisasikan prinsip-prinsip atau keterampilan akademik tertentu, tetapi berdasarkan masalah mengorganisasikan pengajaran di sekitar pertanyaan dan masalah yang kedua-duanya secara penting dan secara pribadi bermakna bagi anak.

b. Berfokus pada keterkaitan antar disiplin yang berpusat pada mata pelajaran tertentu, dan masalah yang akan diselidiki telah dipilih benarbenar nyata agar dalam pemecahannya 
siswa meninjau masalah itu dari banyak mata pelajaran.

c. Penyelidikan autentik untuk mencari penyelesaiannya taterhadap masalah nyata.

d. Menghasilkan produk atau karya dan memamerkannya untuk menghasilkan produk tertentu dalam bentuk karya nyata dan peragaan yang menjelaskan atau mewakili bentuk penyelesaian masalah yang mereka temukan.

Menurut Maulidya (2018:20), terdapat 4 faktor yang mempengaruhi proses dalam problem solving yaitu:

a. Motivasi yang rendah akan mengalihkan perhatian, sedangkan motivasi yang tinggi akan membatasi fleksibilitas.

b. Kepercayaan dan sikap yang salah asumsi dapat menyesatkan. Apabila percaya bahwa kebahagiaan dapat diperoleh dengan kekayaan material, maka akan mengalami kesulitan ketika memecahkan masalah.

c. Kebiasaan untuk mempertahankan pola pikir tertentu atau melihat masalah hanya dari satu sisi saja, kepercayaan yang berlebihan dan tanpa kritis pada pendapat otoritas menghambat pemecahan masalah yang efisie menyebabkan pemikiran menjadi kaku.

d. Emosi dalam menghadapi berbagai situasi, tanpa sadar terlibat secara emosional. Emosi ini mewarnai cara berpikir sebagai manusia yang utuh. Tetapi apabila emosi itu sudah mencapai intensitas yang begitu tinggi, maka dapat mengakibatkan stress dan sulit untuk berpikir efisien.

Model pembelajaran problem solving dapat memberikan bekal kepada siswa berbagai cara menyelesaikan masalah, di mana siswa akan dapat menganalisis materi secara mendalam dan membantu siswa memproses informasi yang telah di dapat (Fahmi dkk.,2017:7). Model pembelajaran problem solving memberikan permasalahan yang ada di kehidupan nyata sebagai sebuah konteks untuk siswa dapat berlatih berpikir cerdas dan kritis, serta dapat belajar memahami sebuah permasalahan dan menganalisis bagaimana cara menyelesaikan permasalahan tersebut dengan tepat (Amrulloh dkk, 2019:103). Selanjutnya dengan adanya berbagai permasalahan tersebut akan membuat siswa berusaha untuk menghubungkan pengetahuanpengetahuan yang telah dimilikinya (Argusni \& Sylvia, 2019:58).

Model pembelajaran problem solving mengupayakan agar siswa bisa berpikir logis, rasional, kritis, cermat, jujur dan efektif.Selain itu, mampu memecahkan masalah dengan memahami masalah tersebut, membuat perencanaan pemecahannya, menyelesaikan masalah tersebut dengan mengecek kembali langkah-langkah yang bisa diupayaka (Manik, 2020:155). Melalui penerapan model pembelajaran problem solving siswa akan ikut berpartisipasi dalam kegiatan pembelajaran, berpikir secara sistematis, mampu merancang suatu penemuan, berpikir kreatif dan realistis, menyelidiki secara baik, dan mampu mengevaluasi dan menafsirkan penemuan (Suhardi dkk, 2020). Oleh karena itu, model pembelajaran problem solving adalah salah satu alternatif dari model pembelajaran yang inovatif, karena adanya reorientasi pembelajaran yang semula berpusat pada guru menjadi berpusat pada siswa.

Model pembelajaran problem solving memiliki beberapa kelebihan yaitu: melatih siswa untuk belajar mandiri, ilmu dan pengetahuan yang didapatkan siswa bersifat nyata dan aplikatif, meningkatkan kemampuan analisis siswa, menumbuhkan rasa bangga dalam diri siswa saat ia berhasil memecahkan masalah yang dihadapi, dan ilmu dan pengetahuan yang didapatkan bersifat permanen sehingga melekat dalam ingatan siswa (Muliawan,2016). Model problem solving cocok untuk meningkatkan kemampuan pemecahan masalah, karena model pembelajaran problem solving memusatkan pada pengajaran dan keterampilan pemecahan masalah yang diikuti dengan 
penguatan keterampilan (Maesari dkk.,2020:14).

Adapun kelemahan model pembelajaran problem solving yaitu: umumnya, guru kesulitan mencari masalah yang sesuai dengan bidang studi, waktu dan proses yang dibutuhkan lebih lama dari model pembelajaran konvensional, untuk beberapa jenis mata pelajaran, masalah yang diberikan kepada siswa membutuhkan biaya tenaga tambahan (Muliawan,2016). Model pembelajaran problem solving melibatkan banyak orang sehingga terdapat langkah-langkah yang membuat siswa cenderung tidak berperan dalam proses pembelajaran. Hal ini menyebabkan siswa yang pasif akan cenderung sulit dalam menyesuaikan dengan suatu masalah yang lebih rumit terutama dalam pemecahan dan penyelesaian masalah (Limbanadi dkk, 2020:775).

Sistem sosial merupakan gambaran tentang peran maupun hubungan guru dan siswa, serta norma yang dibangun dalam model pembelajaran. Guru bertindak aktif dalam pengendalian pembelajaran, namun ada masanya peran guru dan siswa harus seimbang. Kemudian guru merefleksi kegiatan siswa selama pembelajaran (Karwati,2020:150). Sistem sosial menggambarkan hubungan yang hierarkis antara guru dan siswa, dimana keduanya memiliki peran yang berbeda-beda (Susanto,2014). Sistem sosial dalam model pembelajaran dapat diamati saat terjadi interaksi antara guru dan siswa.Interaksi tersebut menggambarkan pola komunikasi yang digunakan saat pembelajaran.Umumnya, interaksi sosial terjadi secara timbal balik antara guru dan siswa, maupun siswa dengan siswa.

Implementasi sistem sosial model pembelajaran problem solving dengan pembelajaran berpusat pada siswa. Peran guru merupakan kegiatan yang menggambarkan bagaimana guru memperlakukan dan memberi respon kepada siswa. Guru berperan sebagai pembimbing, fasilitator, motivator dan mediator (Effendi, \& Fatimah,2019:90).
Sebagai pembimbing, guru sebagai tempat untuk bertanya saat siswa sedang mengalami kesulitan, serta mengarahkan agar siswa secara mandiri mampu mengatasi persoalan tersebut.Sebagai fasilitator dan motivator, guru mempunyai peran sebagai penyedia informasi terkait dengan sumber belajar, literatur, dan sebagainya agar mampu menyiapkan materi dan mempunyai pengetahuan awal yang cukup.Kemudian, memotivasi dan mendorong siswanya agar semangat dalam kegiatan pembelajaran.Sebagai mediator, guru hadir sebagai penengah apabila ada perbedaan dalam berpendapat saat diskusi sehingga didapatkan pemahaman yang benar (Sugiono dkk, 2016:27).

Salah satu faktor paling signifikan yang mempengaruhi keberhasilan akademis siswa adalah sikap.Landasan adanya sikap karena kecenderungan individu yang mengatur pikiran, emosi dan perilaku terhadap suatu objek psikologis. Beberapa sikap didasarkan pada pengalaman, pengetahuan, dan keterampilan dan sumber lain (Guido,2013:2087). Sikap merupakan hal yang sangat penting pada saat berlangsungnya proses pembelajaran (Efendi dkk, 2020:136). Sikap seseorang berbeda-beda dalam merespon suatu rangsangan.Perbedaan tersebut disebabkan karena adanya perbedaan minat, pengalaman, pengetahuan, intensitas perasaan, situasi lingkungan dan sebagainya (Sutarto,2018:24-25).

Adapun sikap yang termuat dalam kurikulum 2013 revisi yaitu sikap spiritual dan sikap sosial.Kompetensi sikap dalam kurikulum 2013 dibagi menjadi dua, yaitu sikap spiritual (KI-1) dan sikap sosial (KI2).Sikap spiritual adalah sikap yang berhubungan dengan pembentukan siswa yang beriman dan bertakwa, sedangkan sikap sosial berhubungan dengan pembentukan siswa yang berakhlak mulia, mandiri, demokratis, dan bertanggung jawab.Sikap spiritual sebagai perwujudan dari menguatnya interaksi vertikal dengan Tuhan Yang Maha Esa, sedangkan sikap sosial sebagai perwujudan eksistensi 
Jurnal Edumaspul, 5 (1), Year 2021- 112

(Weni Sukarni, Astalini, Dwi Agus Kurniawan)

kesadaran dalam upaya mewujudkan harmoni kehidupan (Hasanah dkk, 2017:3).

Sikap seseorang selalu berhubungan dengan kehidupan sosial, karena dengan adanya interaksi sosial akan terlihat sikap seseorang tersebut. Sikap sosial merupakan ekspresi atau tindakan seseorang dalam menyikapi sesuatu dalam kehidupan sosial.Terdapat subjek dan objek dalam sikap sosial. Sikap sosial berkembang dalam suatu kelompok sosial yang dinyatakan dengan cara yang sama dan dilakukan berulang-ulang (Tiara \& Sari, 2019:24). Siswa yang memiliki sikap sosial rendah cenderung kurang tertarik dengan kegiatan yang berorientasi pada berpikir yang disajikan oleh guru untuk menyelesaikan masalah, sehingga siswa tidak komunikatif dalam proses pembelajaran di kelas (Wasiso dkk, 2020:39). Maka, kegiatan pembelajaran dengan pendekatan saintifik yang berbasis pemecahan masalah cocok digunakan untuk meningkatkan sikap sosial siswa.

\section{Simpulan}

Berdasarkan studi literatur mengenai implemntasi sistem sosial dapat disimpulkan bahwa sistem sosial dalam model pembelajaran problem solving belum sepenuhnya terlaksana dengan optimal, dikarenakan kegiatan pembelajaran terkadang masih bersifat teacher centered. Padahal tuntutan kurikulum 2013 revisi pelaksanaan pembelajaran seharusnya bersifat student centered agar terciptanya komunikasi yang dinamis. Keberhasilan penerapan sistem sosial model pembelajaran problem solving membutuhkan peranan guru dan siswa. Selain itu, sistem sosial yang diterapkan belum mengakomodasi perbaikan sikap sosial siswa sebagaimana tuntutan kurikulum 2013 pada kompetensi inti (KI2) mengenai sikap sosial .

\section{Daftar Pustaka}

[1] Abduhan, R., Mulyani, S., \& Budi Utami, B. (2015). Pengaruh Model
Pembelajaran Problem Solving Dan

Student Teams Achievement

Divisions (STAD) Berkombinasi

Drill And Practice Dengan

Memperhatikan Kemampuan

Matematika Terhadap Prestasi

Belajar Siswa (Pokok Bahasan

Konsep Mol Kelas X MIPA SMA

Negeri 3 Surakarta Semester Genap

Tahun Pelajaran 2014/2015). Jurnal

Pendidikan Kimia (JPK), 4(4), 7179.

[2] Alinawati, M. (2014). Implementasi Kurikulum 2013 Pada Sekolah Menengah Kejuruan di Bandung. Edutech, 1(1), 342-260.

[3] Amrulloh, A., Sukamto, \& Hadi, H. (2019). Penerapan Model Problem Solving Berbantu Media Kalkulator Ajaib untuk Meningkatkan Kemampuan Pemahaman Konsep Operasi Hitung. Indonesian Journal Of Educational Research and Review. 2(1),101-109.

[4] Argusni, R., \& Sylvia, I. (2019). Pelaksanaan Model Problem Based Learning Untuk Meningkatkan Kemampuab Problem Solving Siswa kelas XI SMAN 16 Padang. Jurnal Sikola: Jurnal Kajian Pendidikan dan Pembelajaran. 1(1),52-59.

[5] Budiningsih., C.A. (2011). Karakteristik Siswa Sebagai Pijakan dalam Penelitian Dan Metode Pembelajaran. Cakrawala Pendidikan, 30 (1), 160-173.

[6] Buyung. (2014). Pengaruh Model Pembelajaran Problem Solving dan Kemampuan Numerik Terhadap Penguasaan Literasi Matematika di SMP. Jurnal Teknologi Pendidikan, 16(1), 1-12. 
Jurnal Edumaspul, 5 (1), Year 2021- 113

(Weni Sukarni, Astalini, Dwi Agus Kurniawan)

[7] Chania, Y., Havis, M., \& Sasmita, D. (2017). Hubungan Gaya Belajar Dengan Hasil Belajar Siswa Pada Pembelajaran Biologi Kelas X SMA N 2 Sungai Tarab Kabupaten Tanah Datar. Sainstek: Jurnal Sains Dan Teknologi, 8(1):77-84.

[8] Efendi, R., Puspitasari, T.O., \& Pratiwi, N. I. S. (2020). Identifikasi Sikap Implikasi Sosial dari Fisika, Normalitas Ilmuwan, dan Adopsi Sikap Ilmiah. Attractive : Innovative Education Journal. 2(1), 132-142.

[9] Effendi, A. \& Fatimah, A.T. (2019). Implementasi Model Pembelajaran Creative Problem Solving Untuk Siswa Kelas Awal Sekolah Menengah Kejuruan. Teorema: Teori dan Riset Matematika, 4(2), 89-98.

[10] Fadly, W. (2018). Validitas Model "Produksi" Sebagai Alternatif Model Pembelajaran Untuk Mendukung Kurikulum 2013. JNSI: Journal of Natural Science and Integration, 1(2), 145-158.

[11] Fahmi, S., Syahrir, \& Kurniawan. (2017). Penerapan Metode Pembelajaran Problem Solving Untuk Meningkatkan Motivasi dan kemampuan pemecahan masalah Matematika Siswa kelas VIII B SMP negeri 3 Batukliang Tahun Pelajaran 2016/2017. 5(1), 6-10.

[12] Guido, R.M.D. (2013). Attitude and Motivation towards Learning Physics. International Journal of Engineering Research \& Technology (IJERT), 2(11), 20872094.

[13] Gusviani, E. (2016). Analisis Kemunculan Sikap Spiritual dan Sikap Sosial dalam Kegiatan
Pembelajaran IPA Kelas IV SD Yang Menggunakan KTSP dan Kurikulum 2013. EduHumaniora: Jurnal Pendidikan Dasar, 8(1),96100.

[14] Hasanah, H., Nurjaya, I.G., \& Astika, M. (2017). Pengintegrasian Sikap Spiritual dan Sikap Sosial dalam Pembelajaran Teks Ulasan Film/Drama di Kelas XI MIPA SMA Negeri 3 Singaraja. eJournalJurusan Pendidikan Bahasa dan Sastra Indonesia, Undiksha, 7(2), 1-10.

[15] Janawi. (2019). Karakteristik Peserta Didik dalam Proses Pembelajaran. Tarbawy: Jurnal Pendidikan Islam, 6(2), 68-79.

[16] Karwati, U. (2012). Aplikasi Model Pembelajaran Sinektik (Synectic Model). Jurnal Seni \& Budaya Panggung. 22(2),147-159.

[17] Limbanadi, S., Subandi, \& Munzil. (2020). Pengaruh Model Pembelajaran Problem Solving Think Pair Share terhadap pengetahuan Metakognitif siswa. Jurnal Pendidikan:Teori, Penelitian, dan Pengembangan. 5(6),774-779.

[18] Maesari, C., Marta, R., \& Yusnira. (2020). Penerapan Model Pembelajaran Problem Solving Untuk Meningkatkan Kemampuan Pemecahan Masalah Matematika Siswa Sekolah Dasar. Jurnal Pendidikan Dan Konseling,1(2), 12-22.

[19] Manik, I.K. (2020). Penerapan Model Pembelajaran Problem Solving Sebagai Upaya Meningkatkan Prestasi Belajar 
Jurnal Edumaspul, 5 (1), Year 2021- 114

(Weni Sukarni, Astalini, Dwi Agus Kurniawan)

Matematika. Journal of Education Action Research, 4(2), 153-163.

[20] Mardiana, S. \& Sumiyatun.(2017). Implementasi Kurikulum 2013 dalam Pembelajaran Sejarah di SMA Negeri 1 Metro. Jurnal Historia, 5(1), 45-54.

[21] Maulidya, A. (2018). Berpikir dan Problem Solving. Ihya al-Arabiyah: Jurnal Pendidikan Bahasa dan Sastra, 1(1), 11-29.

[22] Mulati, T. S., . K., \& Rejeki, A. S. (2014). Perbedaan Pengaruh Metode Pembelajaran Simulasi Dengan Latihan (Drill) Terhadap Penerapan Pengisian Partograf Pada Mahasiswa Diii Kebidanan. Jurnal Cakrawala Pendidikan, 1(1), 113119.

https://doi.org/10.21831/cp.v1i1.186 7

[23] Muliawan. J. U. (2016). 45 Model Pembelajaran Spektakuler. Yogyakarta: Ar-Ruzz Media.

[24] Muslim, S. R., Studi, P., Matematika, P., \& Siliwangi, U. (2015). dalam pembelajaran kooperatif terhadap kemampuan pemecahan masalah matematik siswa SMK di Kota Tasikmalaya. Jurnal Penelitian Pendidikan Dan Pengajaran Matematika, 1(1), 6572.

[25] Mustoip, S., Japar, M., \& Zulela, M. (2018). Implementasi Pendidikan Karakter. Surabaya: Jakad Publis.

[26] Nurhamidah, I. (2018). Problematika Kompetensi Pedagogi Guru Terhadap Karakteristik Peserta Didik. Jurnal Teori dan Praksis Pembelajaran IPS. Vol 3(1): 27-38 http://dx.doi.org/10.17977/um022v3 i12018p027.

[27] Nurhidayati,

D. D. (2016).

Peningkatan

Manajemen
Bimbingan Kelompok Dengan TeknikProblem Solvingpada Siswa. Psikopedagogia. 5(1).24-32.

[28] Nurwidyastuti, B. \& Wutsqa, D.U. (2016). Pengembangan Model Pembelajaran PBL pada Pelajaran Matematika untuk Meningkatkan Kemampuan Investigasi dan Ranah Afektif. Jurnal Pendidikan Matematika dan Sains, 4 (1),32-42.

[29] Octavia, S. A. (2020). Model-Model Pembelajaran. Deepublish: Sleman.

[30] Pane, A., \& Dasopang, M.D. (2017). Belajar Dan Pembelajaran. Jurnal Kajian Ilmu-Ilmu Keislaman, 03(2), 333-352.

[31] Permendikbud RI. (2013). Nomor 65 tentangStandar Proses Pendidikan Dasar dan Menengah. SALINAN LAMPIRAN.

[32] Salim, M., \& Mujtahidah, N. (2020). Penerapan Kurikulum 2013 Revisi 2018 Dalam Meningkatkan Prestasi Belajar Siswa: Studi Multi Situs di SMP Raden Fatah Batu dan MTs. Ihyaul Ulum Dukun Gresik. AlIdaroh: Jurnal Studi Manajemen Pendidikan Islam, 4(1), 86-107.

[33] Saptono. A.,\& Suparno. (2016). Lingkungan Belajar, Sikap Terhadap Profesi Guru terhadap Intensi Menjadi Guru (Studi pada Mahasiswa Fakultas Ekonomi Universitas Negeri Jakarta). Jurnal Ilmiah Econosains, 14(1), 20-31.

[34] Sari, N., Putri, Y. E., Jannah, N., \& Puspitasari, T. O. (2020). Hubungan Kerja Keras dan Sikap Siswa dalam Pembelajaran IPA (Relationship between Hard Work and Attitudes of Students in Science Learning). SEJ (Science Education Journal), 3(2), 101-112. 
Jurnal Edumaspul, 5 (1), Year 2021- 115

(Weni Sukarni, Astalini, Dwi Agus Kurniawan)

[35] Setiadi, H. (2016). Pelaksanaan Penilaian Pada Kurikulum 2013. Jurnal Penelitian dan Evaluasi Pendidikan, 20(2), 166-178.

[36] Sha'adhah, Z., Hobri, \& Setiawan, T. B. (2013). Penerapan Metode Role Playing (Bermain Peran) untuk Mengurangi Kesalahan Siswa dalam Menyelesaikan Soal Pada Materi Aritmetika Sosial Kelas VII A SMPN 1 Sukowonoso Semester Ganjil Tahun Ajaran 2012/2013. Kadikma, 4(2), 27-38.

[37] Sugiono, Sudarti, \& Sutarto. (2016). Validitas Logis Model Pembelajaran Eskalasi Untuk Pembelajaran Fisika di SMA. Jurnal Pembelajaran dan Pendidikan Sains, 1(1), 23-30.

[38] Suhardi, D., Chaerunnisa, H., \& Santoso, A. S. (2020). Panduan Pengisian Opak Jabar. Deepublish.

[39] Suriadi. (2018). Penyusunan Dokumen Kurikulum 2013 Dalam Konteks Kekinian. Jurnal Manajemen Pendidikan Islam, 2(1), 40-52.

[40] Susanto, A. (2014). Pengembangan Pembelajaran IPS di Sekolah Dasar Edisi Pertama. Jakarta: Prenada Media.

[41] Sutarto. (2018). Pengembangan Sikap Keberagamaan Peserta Didik. Jurnal Bimbingan dan Konseling Islam, 2(1), 21-42.

[42] Taufik, A. (2019). Analisis Karakteristik Peserta Didik. ElGhiroh, 16(1), 2-13.

[43] Tiara, S.K. \& Sari, E.Y. (2019). Analisis Teknik Penilaian Sikap Sosial Siswa dalam Penerapan Kurikulum 2013 di SDN 1 Watulimo. EduHumaniora: Jurnal Pendidikan Dasar, 11(1), 21-30.

[44] Utami, L. O., Utami, I. S., \&
Sarumpaet, N. (2018). Penerapan Metode Problem Solving Dalam Mengembangkan Kemampuan Kognitif Anak Usia Dini Melalui Kegiatan Bermain.Tunas Siliwangi, 3(2), 175-180.

[45] Wahyuni, Y. (2017). Identifikasi Gaya Belajar (Visual, Auditorial, Kinestetik) Mahasiswa Pendidikan Matematika Universitas Bung Hatta. Jurnal Penelitian dan Pembelajaran Matematika, 10(2), 128-32.

[46] Wasiso, A.J., Sukardi, S., \& Winarsih, M. (2020). Pengaruh model pembelajaran dan sikap sosial terhadap hasil belajar sejarah siswa SMA. Jurnal Penelitian Ilmu Pendidikan, 13 (1), 31-40.

[47] Widiawati, C. I. M. K. (2018). Penerapan Model Pembelajaran Problem Solving Dalam Upaya Meningkatkan Kemampuan Menganalisis Teks Eksposisi Peserta Didik Kelas X MIPA 5 SMA Negeri 7 Denpasar Tahun Pelajaran 2017/2018. Widyadari: Jurnal Pendidikan, 19(2), 1-9. DOI: http://doi.org/10.5281/zenodo.14709 $\underline{02}$.

[48] Yarmayani, A., \& Afrila, D. (2018). Analisis Faktor Lingkungan Belajar yang Mempengaruhi Hasil Belajar Siswa. Jurnal Ilmiah Dikdaya, 8(1), 135-149.

[49] Zahara, A., Harun, M.Y., \& Abdi, A.W. (2017). Hubungan Sikap Spiritual Dan Sikap Sosial Dengan Hasil Belajar Ips Terpadu Siswa Kelas Viii Di Smp Negeri 18 Kota Banda Aceh. Jurnal Ilmiah Mahasiswa Pendidikan Geografi FKIP Unsyiah, 2(3), 1-11. 
Jurnal Edumaspul, 5 (1), Year 2021- 116

(Weni Sukarni, Astalini, Dwi Agus Kurniawan) 